\title{
Strategies Employed in Translation of Tourist Guidebooks Culture-specific Items from Persian into English
}

\author{
Masoome Rezaei \\ Department of English Language, East Azarbaijan Science and Research Branch, Islamic Azad University, Tabriz, Iran \\ Davud Kuhi \\ Department of English Language, Maragheh Branch, Islamic Azad University, Maragheh, Iran
}

\begin{abstract}
One of the major duties of every translator is to use an appropriate method in dealing with culturespecific items (CSIs). In this paper an attempt has been made to study the translation of two Iran tourist guidebooks translated by Oksana Beheshti and Amir Hassan Hakimian from Persian into English in order to analyze the strategies the translators have employed for translating CSIs based on Newmark's model and then to explore whether most these CSIs are domesticated or foreignized. For this purpose a number of instances which are highly specific cultural references have been collected and the strategies applied by translators have been identified. According to the obtained results, the most abundant strategies used in the translation of these two corpses are Newmark's transference with the addition of some notes. Therefore, although both domesticating and foreignizing strategies have been used, the most common strategy in the translation of these two tourist guidebooks is foreignization.
\end{abstract}

Index Terms - culture, culture-specific items (CSIs), domestication and foreignization, tourist guidebooks, translation strategies

\section{INTRODUCTION}

By knowing the languages alone it is not possible to guarantee the success of translations. According to Newmark (1995, p. 79) "any old fool can learn a language ... but it takes an intelligent person to become a translator". Paluszliewicz-Misiaczek reports Bell (1991) that "apart from an excellent knowledge of both the source and the target language, which comprises vocabulary and word formation, grammar, spelling and pronunciation, the translator also has to possess so-called "sociolinguistic competence", which helps him to understand the text within its context, to determine its functions and predict who is going to receive it" (Paluszliewicz-Misiaczek, 2005, p. 243-244).

Tourist guidebooks usually include details about a country geographic location and provide some information about its tourist sites, accommodations and sometimes the costumes and culture of its people. Each cultural community has a set of habits, value judgments, classification systems, symbols, ceremonies, etc. which are often peculiar to its nationwide territory. Each word or expression may refer to a concept which is different from one language to another. According to Aixelá CSIs are "those textually actualized items whose function and connotations in a source text involve a translation problem in their transference to a target text, whenever this problem is a product of the nonexistence of the referred item or of its different inter textual status in the cultural system of the readers of the target text" (Aixela, 1996, p. 58). The translation of CSIs in tourism texts constitutes the most serious problem for a translator because he/ she needs to know the source language and the target language well and also get familiar with both cultures. Translators should be able to find a range of possibilities that include all the diversities of translation strategies which can be used to solve the problems of translating CSIs between languages (Maasoum, 2011).

The present descriptive study tries to trace CSIs in translation of two tourism guidebooks and analyze the strategies the translator has employed for translating them into English and did not intend to judge the correctness of translations or appropriateness of the application of translators' ideological presuppositions. After gathering this data the rendering choices have been noted to show either domestication or foreignization is used in the target texts. Newmark's classification of CSIs has been adopted as the theoretical framework of this study.

\section{CUlture-SPECIFIC ITEMS (CSIS) IN TRANSLATion}

\section{A. The Concept of Culture}

Culture is an extremely complex and enormous subject. It has been analyzed by different scholars and translation theorists paid a lot of attention to cross-cultural understanding. A big variety of definitions of the word culture reflect different understanding and different approaches towards this complex concept; however all of them include such 
notions as customs, traditions, beliefs, habits, environment, geographical realia, national literature, folklore and religious aspects (Novels, 2012). Newmark defines culture as "the way of life and its manifestations that are peculiar to a community that uses a particular language as its means of expression" (Newmark, 1988). Vermeer states that "language is part of a culture" (Vermeer, 1989).

Cultural differences exist between countries and this is partially caused by different languages that exist in different countries. Communication with someone who speaks a different language, subscribes to different values and belief structures and maintains a different outlook on life, may lead to misunderstanding and miscommunication, which in turn will lead to an undesired reaction and behavior by the receiver or consumer (Bezuidenhout, 1998). It is very important to understand culture of other people to avoid such miscommunications. These statements prove that "language and culture are inseparable, language and culture are intimately linked, language is culture and culture is language" (Risager, 2006). One language cannot express the meanings of another; instead there is a distinction between the meanings built in the SL and the meanings that must be captured and expressed in TL (Thriveni, 2001). In this regard, when people speak different languages it predisposes them to think differently. Therefore, translation is not simply seeking meanings in another language, but finding appropriate ways of saying things in another language. If we consider culture as a complex of beliefs, attitudes, values, and rules which a group of people share, then the writer of the source text assumes the beliefs, attitudes, values, and rules of the audience for which he writes. Therefore we can say every language possesses specific words and phrases for special kinds of culture-specific concepts: events, customs or objects. In order to understand the source text the translator at first needs to understand these attitudes and values and then it is possible to translate them into the TL. To sum up, translation from one language to another cannot be done without knowledge of the two cultures.

\section{B. Culture-specific Items: Definition and Types}

According to Newmark translation is a craft consisting in the attempt to replace a written message and/or statement in one language by the same message and/or statement in another language (Newmark, 1981, p. 7). However, with CSIs this often seems to be impossible as the meanings which lie beyond these expressions are always strongly linked to a specific cultural context (Terestyényi, 2011).

It is not always clear which words and expressions should be considered CSIs, even in the literature of translation several names exist for these items: realia, culture-specific items and culturally bound items. In the field of translation studies realia - also culturally-bound, culture-specific expressions - cannot be easily well-defined. They do not mean only objects, but also words that signify concepts that are related to a specific culture (Terestyényi, 2011).

Franco Aixelá (1996, p. 58) defines CSIs as "those textually actualized items whose function and connotations in a source text involve a translation problem in their transference to a target text, whenever this problem is a product of the non-existence of the referred item or of its different intertextual status in the cultural system of the readers of the target text".

Some scholars have classified CSIs into some categories. Newmark (1988, p. 94-95) defines culture as the way of life and its manifestations that are peculiar to a community that uses a particular language as its means of expression. He described five "cultural categories" and their sub-categories that CSIs may come from. Those categories are as follows: 1) Ecology: flora, fauna, hills, winds, plains; 2) Material culture (artifacts): food, clothes, houses and towns, and transport; 3) Social culture: work and leisure; 4) Organizations, customs, activities, procedures, and concepts: political and administrative, religious, and artistic; and 5) Gestures and habits.

Vlahov and Florin speak of realia and categorize these items as follows: 1) Geographical (geographic formations, man-made geographical objects, flora and fauna that is special to a certain place); 2) Ethnographic (food and drink, clothing, places of living, furniture, pots, vehicles, names of occupations and tools); 3) Art and culture (music and dance, musical instruments, feasts, games, rituals and their characters); 4) Ethnic (names of people, nicknames); and 5) Sociopolitical (administrative-territorial units, offices and representatives, ranks, military realia) (Terestyényi, 2011).

\section{TRANSLATION STRATEGIES FOR CULTURE-SPECIFIC ITEMS}

Translators use different methods or strategies to transfer the essence of the original text. According to Venuti's major work, The Translator's Invisibility (1995), translation of texts from one culture into another usually requires more than a simple choice of what gets translated or what does not, i.e. it requires a choice between two translation procedures, namely domestication and foreignization (Zare-Behtash, 2009). Domestication means making the text recognizable and familiar and thus bringing the foreign culture closer to that of the readers in the target culture, while foreignization means taking the reader to the foreign culture and making him or her feel the linguistic and cultural differences (Lindfors, 2001). It encourages a translation practice in which traces of the foreign are left as much as possible within the translated text. In any translation project, the initial decision between which procedures to adopt, either a domesticating or a foreignizing one, may affect the whole translation process, leading either to a TT that is easily recognizable and thus readily accessible to the target readership, or to a text that constantly reminds target readers of cultural difference (Zare-Behtash, 2009).

Different scholars have analyzed the strategies and procedures involved in the translation of CSIs, suggesting various classifications of such strategies. One of the pioneers in this field was Newmark. He introduces the following translation 
strategies for finding an appropriate equivalence for CSIs: Transference: the process of transferring a SL word to a TL text as a translation procedure (Newmark, 1988, p.81). Naturalization: succeeds transference and adapts the SL word first to the normal pronunciation, then to the normal morphology of the TL (Newmark, 1988, p.82). Cultural equivalent: an approximate translation where a SL cultural word is translated by a TL cultural word (Newmark, 1988, p.82). Descriptive equivalent: the translator uses some descriptions to clarify the meaning for his audience. Functional equivalent: applied to cultural words, requires the use of a culture-free word, sometimes with a new specific term; it therefore neutralizes or generalizes the SL word (Newmark, 1988, p.83). Synonymy: is defined as a near TL equivalent to an SL word in a context, where a precise equivalent may or may not exist. This procedure is used for a SL word where there is no clear one-to-one equivalent (Newmark, 1988, p.84). Componential analysis: is defined as comparing a SL word with a TL word which has a similar meaning but is not an obvious one-to-one equivalent, by demonstrating first their common and then their differing sense components. Normally the SL word has more specific meaning than the TL word and the translator has to add one or two TL sense components to the corresponding TL word in order to produce a closer approximation of meaning (Newmark, 1988, p. 114). Through-translation: is the literal translation of common collocations, name of organizations, and the components of compounds and perhaps phrases, which is also known as calque or loan translation (Newmark. 1988, p.84). Shifts or Transpositions: involves a change in the grammar from SL to TL. The first type of shift occurs when there is a change from singular to plural. The second type of shift is required when an SL grammatical structure does not exist in the TL. Finally the third type of shift is the one where literal translation is grammatically possible but may not accord with the TL (Newmark, 1988, p. 85-86). Recognized translation: is the official or the generally accepted translation of any institutional term (Newmrk, 1988, p.89). Modulation: in this strategy the translators try to create the message of the SL in the TL in conformity with the current norms of the TL (Maasoum, 2011). In modulation the SL and the TL may be different in terms of perspective (Newmark, 1988, p.88). Compensation: is said to occur when loss of meaning, sound- effect, metaphor or pragmatic effect in one part of a sentence is compensated in another part, or in contiguous sentence (Newmark, 1988, p.90). Paraphrase: is an amplification or explanation of the meaning of a segment of the text. It is used in an 'anonymous' text when it is poorly written, or has important implications or omissions (Newmark, 1988, p.90). Couplets, Triplet, and Quadruplet: this strategy occurs when the translator combines two or more than two different procedures for dealing with a single problem. They are particularly common for cultural words, if transference is combined with a functional or a cultural equivalent (Newmark, 1988, p.91). Notes: is additional information in a translation. In This strategy the translator should explain the meaning of the word or phrases in the note (Newmark, 1988, p.91).

The classification of procedures in translation of CSIs in the light of domestication and foreignization strategies will be according to table I.

TABLE I.

TAXONOMIES OF PROCEDURES RELATED TO DOMESTICATION AND FOREGNIZATION STRATEGIES BY NEWMARK

\begin{tabular}{|l|l|}
\hline Domestication & Foreignization \\
\hline Synonymy & Transference \\
Fultural Equivalence & Through Translation \\
Descriptive Equivalence & Recognized Translation \\
Shifts & Compensation \\
Modulation & Notes \\
Naturalization & \\
Paraphrase & \\
Componential analysis & \\
\hline
\end{tabular}

In this study Newmark's classification is used as the framework to analyze the translation strategies used in translating CSIs. The instances were selected from two tourist guidebooks Travel Guide to Fars and Iran Tourist Guide, and their translations into English by Oksana Beheshti and Amir Hassan Hakimian.

\section{RESUlts AND ANALYSIS}

This section is based on collecting CSIs from the two tourist guidebooks and then according to the above mentioned categories they are divided into the following groups: Geographical items, Ethnographic items, Ethic items, and artistic and cultural items.

\section{A. Translation of Geographical Items}

According to Newmark (1988) when the translators face the geographical names they should use the method of transference. Geographical names fall into Newmark's first categorization ecology and also Vlahov and Florin's first categorization geographical items.

Tappeh (hill) Silak in Kashan

ד جشم انداز طبيعى كوبير The natural landscape of Kavir (desert)

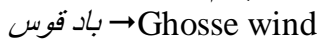

جqanats (subterranean aqueduct, used as part of the water-supply system in desert regions). 
In these examples the translator transferred the SL words into the TL. For some of the examples the translator used transference with the addition of notes to explain the exact meaning of them.

L درختان تبريزى

is a tree with a dense crown, and narrow oval. The ben has thicker trunk and gradually narrows. Slender branches cover almost the entire length of the shaft. Its scientific name is Populus nigra that means black poplar: large European poplar.

Based on Oxford dictionary, Lombardy poplar is a black poplar of a variety which has a distinctive tall, slender columnar form. It arose as a mutation in Italy and is widely cultivated. It can be the best and "nearest TL equivalent" for in Persian.

This equivalent in English can have the same sense on the reader, so the translator used Newmark's synonymy to translate this sample.

$$
\text { seasonal summer and winter quarters }
$$

According to Oxford dictionary winter quarter means "accommodation for the winter, especially for soldiers". حراه in English means a pasture, the land covered with grass and other low plants suitable for grazing animals, especially cattle or sheep. The nomads in Iran change their pastures according to seasonal changes.

In English the translator used seasonal summer and winter quarters as an equivalent for جراكاه هاى بيلاقى و قشلاقفى however it cannot have the same connotative meaning. So according to Newmark's statement it is not an "accurate" equivalent for the Persian word. The translator here used Newmark's cultural equivalence.

The samples show that the most abundant strategy that is used to translate geographical names is Newmark's transference. However, for translating درختان تبريزى he used synonymy and for جراكاه هاى بيلافى و فثشلافى a cultural equivalence is used. Table II provides the strategies used while translating geographical names into English.

TABLE II.

TRANSLATION STRATEGIES USED IN TRANSLATING GEOGRAPHICAL NAMES
\begin{tabular}{|l|l|}
\hline Foreignization & Domestication \\
\hline Transference + Note $\rightarrow 3$ & Cultural Equivalence $\rightarrow 1$ \\
Transference $\rightarrow 1$ & Synonymy $\rightarrow 1$ \\
\hline
\end{tabular}

\section{B. Translation of Ethnographic Items (Food and Drinks, Places of Living, Tools and Furniture)}

\section{Food and Drinks}

The theorist, Mona Baker, claims that culture "may relate to religious belief, a social custom, or even a type of food" (Baker, 1992). Food is an important part of certain cultures; people from one culture could be suffering from hunger and the desperate need of food, and others can eat whatever they like and as much as they want. The area of food items can be classified into Newmark's second categorization material culture and Vlahov and Florin's second categorization ethnographic items.

Chelokabab (steamed rice with grilled lamb or beef)

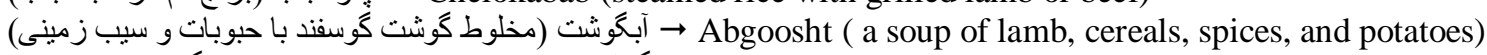

Fesenjan (poultry, especially goose or duck, ground walnut, pomegranate syrup, sugar and spice)

ד Dolmeh (a mixture of meat, vegetables and other materials wrapped in the fresh leaves of grapevine).

$\dot{\varepsilon} \rightarrow$ Doogh (yogurt drink)

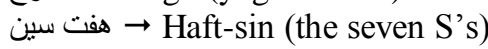

M sabzeh (various home-grown shoots)

ه sib (apple)

ـ serkeh (vinegar)

$\rightarrow$ senjed (jujube fruit)

M sir (garlic)

M somagh (sumac)

ج سمنو $\rightarrow$ samanu (a sweet, thick paste made from the juice of crushed grains of green wheat)

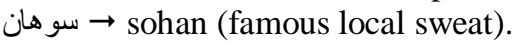

Different kinds of Iranian breads are Sangak, Lavash, Taftoon, and Barbary.

$$
\text { خاويار Caviar }
$$

The examples show that it was difficult for the translator to translate food items and names of dishes. These items are left in Persian in the English version of the text. In most cases the translator, used additional translations in brackets; in this way the reader can easily understand what the words mean in the source language. For هنت سين the translator used the Persian words in the translation to emphasis the letter $w$ at the first of each word and then brought the meaning of each item in the brackets. And finally in the case of خاويار (Caviar) Newmark's strategy of recognized translation is used because the term caviar is "generally accepted" in TT. Table III provides the strategies used for translating food and drinks into English. 
TABLE III.

\begin{tabular}{|l|l|}
\hline TRANSLATION STRATEGIES USED IN TRANSLATING FOOD AND DRINKS \\
\hline Foreignization & Domestication \\
\hline Transference + Note $\rightarrow 14$ & \\
Transference $\rightarrow 4$ & \\
Recognized translation $\rightarrow 1$ & \\
\hline
\end{tabular}

\section{Place Names}

This section will analyze different strategies were used in translating place names. Place names are the sub-categories of Newmark's second general categorization which is material culture, since they are kinds of places, housing and towns. And according to Vlahov and Florin these samples can be categorized as ethnographic items (their second category).

M GhahveKhane (coffeehouse)

ايوان eivan (a large vaulted porch opens at one end)

ד mihrab (niche or decorative panel in the wall of the mosque, showing to the prayers the direction of qibla (Mecca)

( ) عمارت كلاه فرنكى pavilion called Kolah-farangi ("the European Hat").(Kolah-farangi: a little garden pavilion)

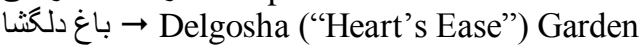

Pazar ("Eye-Catching”) Garden

خ khaneqah (dervishes' cloisters)

ד howz-khaneh (basement vaulted chamber arranged around a middle pool found in Iranian traditional houses and sometimes other buildings)

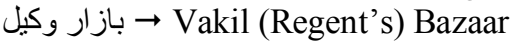

ד biruni and andaruni (Biruni: part of the traditional Iranian house allocated for guests and accommodating the reception area, Andaruni: part of the traditional Iranian house reserved for the living quarters of the family)

ד شى رازى ايش ("شهر اسرار") Shi-razi-ish, "the town of secrets" (perhaps the place where the royal archieve had been kept before Perspolis was founded)

In these samples Newmark's strategy of transference is used with the addition of some notes.

ب Sar-e Howz-e Aqa bazaar

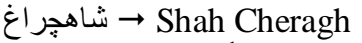

> Darb-e-Imamzadeh Bath

$\rightarrow$ the Tup-Khaneh Square

These samples are the proper names of different places in Iran. Here the translator used Newmark's transference but he did not give any notes to explain about the meaning of them.

سربينه cloakroom

According to Oxford dictionary Cloakroom is a room in a public building where outdoor clothes or luggage may be left.

According to Dehkhoda dictionary سربينه means رختكن حمام, an area outside the bathroom where people can take off their clothes before going into the bathroom.

$\rightarrow$ alcove

According to Wikipedia شاه نشبين is a niche within panjdari a little higher than the ground and usually is for elders and guests.

As presented in Oxford dictionary an Alcove is a recess in the wall of a room or garden.

$\rightarrow$ silver casket

According to Oxford dictionary a Casket is a small ornamental box or chest for holding jewels, letters, or other valuable objects; a coffin.

Based on Dehkhoda ضريح is the building on the graves of religious leaders.

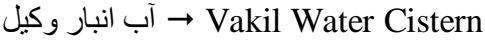

According to Oxford dictionary Cistern means a tank for storing water, especially one supplying taps or as part of a flushing toilet.

Based on Moin Dictionary آب /نبارis a special place usually under the ground for storing water.

ک كرمابه bath

كر كابه refers to a public bath used in Iran and it had many different parts. But bath is not an accurate equivalence for it.

For the samples in this part the translator used Newmark's cultural equivalent. In all these examples the English words are not accurate equivalences for the SL items.

ج جايخانه $\rightarrow$ teahouse

Friday Mosque of Surian

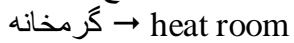

According to Newmark (1988, p.84) for translation of common collocations, names of organizations, the components of compounds and perhaps phrases the translator can use a literal translation that is known as calque or loan translation. 
He prefers the more transparent term through-translation. As you can see for translating the compound nouns here the translator used through-translation.

Karim Khan's Kiosk

means a palace, a supreme house. The definition of kiosk in Oxford dictionary is: a light open pavilion or summer house (in Turkey and Iran).

In English translation of كوشك the translator has chosen the term kiosk which is "generally accepted" in TT. Here the translator used Newmark's Recognized translation.

In the area of places in most cases the translator used the Persian words because the names of places are among proper nouns and the translator could not find an equivalent in the TL. For most of the examples he used the Persian words and then explained about them in brackets or the glossary at the end of the book. Among the examples of this group we can talk about ايوان, شاهجر اغ ,باز ار وكيل, باغ دلكثا, خانقاه, محر , etc. The most abundant strategy is Newmark's transference and notes. There are some other examples that the translator used different strategies to translate them. In table IV the strategies that are used for translating place names are shown.

TABLE IV.

TRANSLATION STRATEGIES USED IN TRANSLATING PLACE NAMES

\begin{tabular}{|l|l|}
\hline Foreignization & Domestication \\
\hline Transference + Note $\rightarrow 12$ & Cultural Equivalent $\rightarrow 5$ \\
Transference $\rightarrow 4$ & \\
Through translation $\rightarrow 3$ & \\
Recognized translation $\rightarrow 1$ & \\
\hline
\end{tabular}

Tools and Furniture (Crafts)

جاجيم $\rightarrow$ jajim (coarse blanket)

كبه $\rightarrow$ gabeh (a traditional form of carpet)

$\rightarrow$ Minbar (pulpit consixting of a small set of steps from where a sermon is delivered by a mullah)

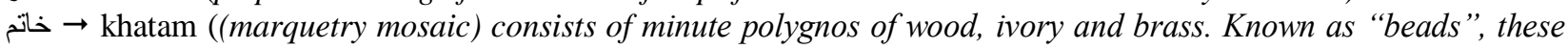
elements are formed of rods, triangular in section, glued together and then sliced. The beads are then fixed to the wood surface of the object intended for the decoration.)

Mashkul (a Sufi begging bowl used by dervishes for collecting alms)

Sرسى Korsi (a low table with a brazier underneath and covered by a thick quilt overhanging it on all sides).

For these samples the translator could not find an English equivalence, so he used the strategy of transference with the addition of notes to explain the examples.

ا lamps and candle sticks

定 bags of lamb-skin.

定 $\rightarrow$ Loom

Based on oxford dictionary, loom is an apparatus for making fabric by weaving yarn or thread.

In these three samples the translator used an approximate translation; the SL cultural words are translated by TL cultural words. Bag, lamp and loom are not "accurate" equivalents for دار قاليبافى and فانوس , Tشك Strategy used here is Newmark's cultural equivalent.

ک Rلاب ياش Rosewater sprinkler

In this example it seems that the translator chose a word-for-word translation. The strategy used here is Newmark's through translation.

ق hand-woven carpets

It is observable that the translator used some words to describe the clear meaning for the reader of the TT. The translation strategy that is used here is Newmark's descriptive equivalent.

S كليم (short-napped coarse carpet)

The definition of كليج in Oxford dictionary is: a flat-woven carpet or rug made in Turkey, Kurdistan, and neighboring areas.

In English translation of this word the translator has chosen the term kilim which is "generally accepted" in TT. So we have Newmark's recognized translation. The translator also used notes to explain the exact meaning of this item.

From the examples this conclusion can be drawn that the most common strategy used for translating crafts into English is Newmark's transference and notes. However, some other strategies are used to translate these culturespecific items. Table V provides the strategies that are used while translating crafts into English.

TABLE V.

TRANSLATION STRATEGIES USED IN TRANSLATING PLACE NAMES

\begin{tabular}{|l|l|}
\hline Foreignization & Domestication \\
\hline Transference + Note $\rightarrow 6$ & Cultural Equivalent $\rightarrow 3$ \\
Recognized translation $\rightarrow 1$ & Descriptive Equivalent $\rightarrow 1$ \\
Through translation $\rightarrow 1$ & \\
\hline
\end{tabular}

\section{Translation of Ethic Items (Names and Nicknames)}


In this section the translation strategies used in translating personal names in English versions of the two corpus of this study are examined. All these examples fall into Vlahov and Florin's fourth categorization Ethnic items (names of people and nicknames).

ب Nader Shah (King Nader)

(بbu Abdollah Mohammad ibn Khafif, famous as Sheikh Kabir ("Great Sheikh") (Sheikh: (here) leader of the Sufi order)

dynasties of Achaemenians, Sasanians, and Zand

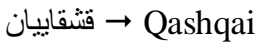

In all these samples the translator used Newmark's transference and for some of them provided notes. Social system of a country can be related to its social classes and groups and they can have special names. These names are in group of proper nouns. Therefore the translator tried to transliterate Persian words into English. Table VI provides the strategies that are used while translating personal names into English.

TABLE VI.

TRANSLATION STRATEGIES USED IN TRANSLATING PERSONAL NAMES

\begin{tabular}{|l|l|}
\hline Foreignization & Domestication \\
\hline Transference $\rightarrow 4$ & \\
Transference + Note $\rightarrow 2$ & \\
\hline
\end{tabular}

\section{Translation of Artistic and Cultural Items (Feasts)}

Feasts (holidays and festivals) reflect culture, history, and religious practices of countries. Some holidays are similar to those celebrated throughout many other parts of the world, while others are unique to a country. In this section the translation of some holidays and festivals mentioned in the two corpus of this study will be analyzed. All the examples fall into Newmark's third categorization Social Culture (leisure) and Vlahov and Florin's third categorization Art and Culture (feasts).

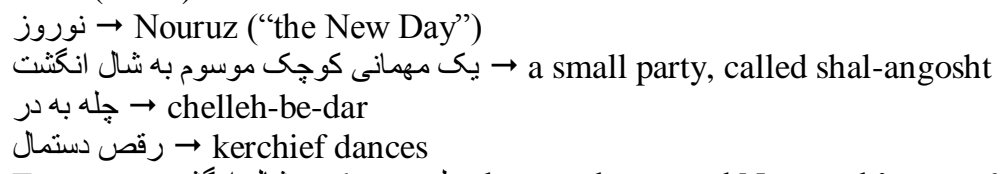

For شله به در and the translator used Newmark's transference, and for the translation of رقص دست انكشت ,نوروز he used Newmark's through translation. Table VII provides the strategies that are used while translating crafts into English.

TABLE VII

TRANSLATION STRATEGIES USED IN TRANSLATING HOLIDAYS AND FESTIVALS
\begin{tabular}{|l|l|}
\hline Foreignization & Domestication \\
\hline Transference $\rightarrow 2$ & \\
Transference + Notes $\rightarrow 1$ & \\
Through Translation $\rightarrow 1$ & \\
\hline
\end{tabular}

\section{DiSCUSSION AND CONCLUSION}

It can be clearly seen from the results that the most abundant strategies employed by translators in the process of translating CSIs in the two tourist guidebooks Travel Guide to Fars and Iran Tourist Guide are Newmark's Transference + Notes (38), and Transference (15) which rank the highest. In some cases the strategies of Through translation (5), Recognized translation (3), Cultural equivalence (9), Descriptive equivalence (1) and Synonymy (1) are used, however, the number of their appearance is not significant. As Newmark (1988) mentions, "Transference is the process of transferring an SL word to a TL text as a translation procedure". "Transference gives "local color," keeping cultural names and concepts". All of this bears witness to the fact that the translators tend to foreignize the cultural elements in these two tourist guidebooks. They tried to preserve the meaning of the SL cultural norms and their foreignness to the TL text and a number of SL cultural words were borrowed and introduced into the TL culture.

\section{REFERENCES}

[1] Aixelá, J. F. (1996). Culture-specific items in translation. Translation, power, subversion, 8, 52-78.

[2] Baker, M. (1992). In other Words. London: Routledge.

[3] Bell, R. T. (1991). Translation and translating (p. 15). London: Longman.

[4] Bezuidenhout, I. (1998). A discursive-semiotic approach to translating cultural aspects in persuasive advertisements. Retrieved November, 29, 2005.

[5] Lindfors, A. M. (2001). Respect or ridicule: translation strategies and the images of a foreign culture. Helsinki English Studies, $1,29$.

[6] Maasoum, S. M. H., \& Davtalab, H. (2011). An Analysis of Culture-specific Items in the Persian Translation of "Dubliners" Based on Newmark's Model.Theory and Practice in Language Studies, 1(12), 1767-1779 
[7] Newmark, P. (1981). Approaches to translation (Vol. 1, p. 982). Oxford: Pergamon Press.

[8] Newmark, P. (1988). A textbook of translation (Vol. 1, p. 988). New York: Prentice Hall.

[9] Newmark, P. (1995). Paragraphs on Translation, Clevdon/Philadelphia/Adelaide: Multilingual Matters Ltd.

[10] Novels, J. H. S. (2012). VERTIMAS/TRANSLATION.

[11] Paluszkiewicz-Misiaczek, M. (2005). Strategies and Methods in Dealing with Culture Specific Expressions on the Basis of Polish-English Translations of Certain Administrative and Institutional Terms. In Proceedings from the Eighth Conference of English, American and Canadian Studies:(linguistics, methodology and translation) (Vol. 3, p. 243). Masaryk University.

[12] Risager, K. (2006). Language and culture: Global flows and local complexity. Multilingual matters.

[13] Terestyényi, Enikő, (2011). Translating Culture-specific Items in Tourism Brochures. In SKASE Journal of Translation and Interpretation [online]. 2011, vol. 5, no. 2.

[14] Thriveni,C. (2001). Cultural Elements in Translation, The Indian Perspective, Available at: http://accurapid.com/journal/19culture.htm.

[15] Venuti, L., (1995). The translator's invisibility: A translation history of translation. London and New York: Routledge.

[16] Vermeer, H. (1989). "Skopos and Commission in Translational Activity." In Venuti, L. The Translation Studies Reader. London: Routledge.

[17] Zare-Behtash, E. (2009). A Diachronic Study of Domestication and Foreignization Strategies of Culture-Specific Items: in English-Persian Translations of Six of Hemingway's Works/Esmail Zare-Behtash, Sepideh Firoozkoohi. World Applied Sciences Journal, 7(12), 1576-1582.

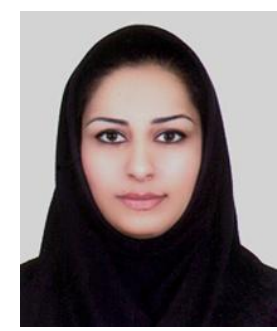

Masoome Rezaei was born in Zahedan, Iran; in 1984. She lives in Zahedan. She is an M.A student of English translation in Islamic Azad University, East Azarbaijan Science and Research Branch. She received her B.A in the same major in Maritime University of Chabahar in Iran in 2007. She teaches English to students at university (Islamic Azad University-Zahedan Branch) and she is an English teacher in some institutes.

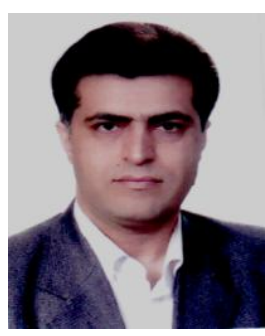

Davud Kuhi, PhD in applied linguistics, is a member of English Language Department at Islamic Azad University, Maragheh Branch, Iran. He has been teaching Linguistics, Sociolinguistics and Discourse Analysis in postgraduate programs, and has been researching mainly on academic discourse issues". 